\title{
Histology of the liver of Oligosarcus jenynsii (Ostariophysi, Characidae) from Los Padres Lake, Argentina
}

\author{
Gladys M. Petcoff, Alcira O. Díaz, Alicia H. Escalante \& Adriana L. Goldemberg
}

Departamento de Biología, Facultad de Ciencias Exactas y Naturales, UNMdP, Funes 3250, 3º piso, (B7602AYJ) Mar del Plata, Argentina. (gpetcoff@mdp.edu.ar)

\begin{abstract}
The liver is an organ notable for its sensitivity to a great variety of environmental factors. It is composed of a parenchyma divided into irregular lobules by the exocrine pancreas or hepatopancreas; the pancreatic cells are arranged around a branch of the portal vein. The hepatocytes are radially arranged in cords around a central sinusoid. The liver histomorphology and the organization of exocrine pancreatic tissue of $O$. jenynsii (Günther, 1864) is similar to the acinar morphology of many teleosts, including freshwater and marine species. The aim of the present work was to carry out the histological analysis of the liver of Oligosarcus jenynsii, one of the most common species inhabiting Los Padres Lake (Buenos Aires Province, Argentina).
\end{abstract}

KEYWORDS. Liver, histology, characid, freshwaters.

RESUMEN. Histología del hígado de Oligosarcus jenynsii (Ostariophysi, Characidae) de la Laguna de Los Padres, Argentina. El dientudo Oligosarcus jenynsii (Günther, 1864) es una de las especies más comunes que habita en la Laguna de Los Padres. Se ha realizado el análisis histológico del hígado del dientudo, un órgano destacable por su sensibilidad a una variedad de factores del medio ambiente. El hígado está compuesto por un parénquima con hepatocitos dispuestos en cordones alrededor de un sinusoide central. El parénquima se halla dividido en lóbulos irregulares por el páncreas exócrino o hepatopáncreas, que posee una disposición acinar y cuyas células se organizan alrededor de una rama de la vena porta. La histomorfología del hígado y la organización del tejido pancreático exócrino de Oligosarcus jenynsii es similar a la de muchos peces teleósteos, tanto marinos como de agua dulce.

PALABRAS ClAVE. Hígado, histología, dientudo, agua dulce.

The liver is a mixed gland surrounded by a thin capsule of connective tissue, the Glisson capsule, dividing the parenchyma into lobules and lobuli. The histological unity of the liver is composed of the liver lobuli, with classic, portal and acini conceptions. The liver has two types of irrigation: one constituted by the hepatic artery, which provides arterial blood to the gland, and the other derived from the portal vein, carrying blood from the esophagic and gastrointestinal tracts, from spleen and pancreas (Ross et al., 2003).

In vertebrates, the liver has a primary array based on hepatocytes, bile canaliculi and sinusoids, and structural differences occur among species in stroma and parenchyma three-dimensional organization.

Three patterns of organization of vertebrate hepatic parenchyma have been described by EuRell \& HAENSLY (1982): 1) the first pattern of hepatic parenchyma arrangement consists of hepatocytes, which are radially arranged around a central vein in interconnecting laminae of two cells thickness, sinusoids separating each lamina. Bile canaliculi are located between adjacent hepatocytes. This pattern corresponds to the muralium or trabecular type, originally established by ElíAs \& BENGELSDORF (1952) for birds and mammals; 2) in the second pattern, sinusoids form an extensive network around the periphery of hepatocytes tubules. A bile canaliculus forms the center of the tubule. This pattern has been described in the "hagfish" Myxine glutinosa (Mugnaini \& HARBoE, 1967); 3) hepatocytes are arranged in anastomosed laminae around the central vein. The bile canaliculi are intracellular (LANGER, 1979; CHAPMAN, 1981). This pattern has been established in teleost fish following the classic tubular pattern.

As teleostean hepatic organization is concerned, several microscopic anatomy and histochemistry studies have been done on the liver of marine species, such as the hake Merluccius hubbsi, the white croaker Micropogonias furnieri, and the stripped weakfish Cynoscion guatucupa (Díaz et al., 1999). Among freshwater species, the histology and ultrastructure of the liver of the channel catfish Ictalurus punctatus, the tigerfish Hydrocynus forskahlii, the trout Oncorhynchus mykiss and the goldfish Carassius auratus have been described (Hinton \& Pool, 1976; GeYer et al., 1996).

Freshwater fishes play different roles in trophic webs of lakes. The characid Oligosarcus jenynsii (Günther, 1864) inhabits vegetated waters, where it feeds mainly on shrimps, amphipods, larvae and adults of insects, and secondarily on microcrustaceans, algae and plant remains. The older specimens frequently prey on fish. Thus, $O$. jenynsii can be a primary, secondary, third, fourth or fifth link in the food web (Menezes, 1969; Ringuelet, 1975; Escalante, 1983).

The aim of the present work was to characterize the histological structures of the liver of $O$. jenynsii inhabiting Los Padres Lake, within the frame of a wider investigation that involves physical, chemical and biological variables frequently used as descriptors of the trophic status of aquatic ecosystems.

\section{MATERIAL AND METHODS}

Los Padres Lake, with an area of $2.16 \mathrm{~km}^{2}$, is located at $37^{\circ} 56^{\prime} 30^{\prime \prime} \mathrm{S} ; 5^{\circ} 44^{\prime} 30^{\prime \prime} \mathrm{W}$, in Buenos Aires, Argentina, and considered an attractive place for tourism, sports, and fishing (Campana et al., 2001; Petcoff et al., 2002). Its watershed comprises an influent stream, Los Padres Creek, which flows through agricultural land before entering the lake. Oppositely to this stream, the lake drains into an effluent, La Tapera Creek, which runs towards the sea (GonZÁLEZ 
SAGRARIO et al., 1998, 2002; MiglioranZA et al., 1999, 2002).

Fifteen specimens of the characid $O$. jenynsii were collected alive using a fishing rod. Their length ranged from 121 to $175 \mathrm{~mm}$. The fish were carried immediately to the laboratory, where they were killed by a sudden blow on the head. For histological study, the liver was removed and fixed in $10 \%$ formalin and formol-buffer during 24 hours. The material was dehydratated and embedded in paraffin, and cut in $4 \mu \mathrm{m}$ thick sections.

The histological technique for routine was hematoxylin and eosin (H/E). The technique of Masson's trichrome stain was used for nuclei, collagen, muscle; Mallory's trichrome stain was used for muscle and connective tissue; Periodic acid-Schiff (PAS) for glycoproteins (GPs) with oxidizable vicinal diol and/or glycogen and Gomori argentic impregnation for reticular fibers (Magalhães Castro de Tolosa et al., 2003).

Photographs were taken using a microscope, with a 100ASAfilm.

\section{RESULTS}

The liver of Oligosarcus jenynsii is composed of a parenchyma covered by a thin capsule of connective tissue. It is divided into irregular lobules by the exocrine pancreas or hepatopancreas, associated to connective tissue. Even though they can not be considered true hepatic triads, bile ducts associated to blood vessels are often found, to which that name is given.

Within the parenchyma, the hepatocytes are radially arranged in cords around a central sinusoid. The lumen of the sinusoids contains mainly erythrocytes and macrophages. Large cells resting on the luminal surface of the sinusoid endothelium are present; these cells are known as Kupffer cells. Sinusoids are covered by typical endothelial cells with flatten nucleus (Fig. 1). With argentic impregnation, a mesh of reticular fibers between the sinusoids and the trabecules of hepatocytes was observed. Hepatocytes vary from polyhedral to round shape. Each hepatocyte contains a large, round, and central nucleus with a prominent dark nucleolus.
Veins are scattered through the liver parenchyma without a well-defined arrangement, and they are surrounded by hepatic parenchyma or pancreatic tissue, sometimes accompanied by an artery or a bile duct (Fig. 2).

The main stored substances in liver cells are glycogen and lipids. With PAS reaction, large and rosette-shaped glycogen deposits were identified throughout the cellular parenchyma. The H/E staining method shows the appearance of vacuolar structures in the hepatic cells, probably due to the presence of lipids.

The exocrine pancreas or hepatopancreas has an acinar arrangement, separated from hepatic parenchyma by a thin layer of connective tissue. The pancreatic cells are arranged around a branch of the portal vein, separated by a basal membrane and reticular fibers (Fig. 3). The hepatopancreatic cells have a particular arrangement, in which the basal region of the inner row of cells is in contact with the basal membrane of the vein, while the basal region of the outer row contacts with the outer layer of connective tissue. The exocrine cells are tall and columnar, spherical nucleus is basally located, with a prominent dark nucleolus. Zymogen granules are located in the apical ends of these cells. Microscopical observations showed that the pancreatic cells are differentiated from hepatic tissue by their basophilic basal pole and eosinophilic apical cytoplasm.

The epithelium of bile ducts is simple. Its epithelial cells are cuboidal or cylindrical, and with Masson's trichrome stain the cells were surrounded by dense connective tissue (blue) and some smooth muscle fibers (red). The epithelial cells have spherical nucleus and a PAS-positive brush border. Among them, there are sometimes rodlet cells. Nerves are found throughout the hepatic parenchyma.

\section{DISCUSSION}

The study of the microscopic anatomy of the liver of Oligosarcus jenynsii showed a typical structural organization comparable to that of most teleosts. The parenchyma does not exhibit the classic liver lobule arrangement determined by blood vessels and bile ducts,

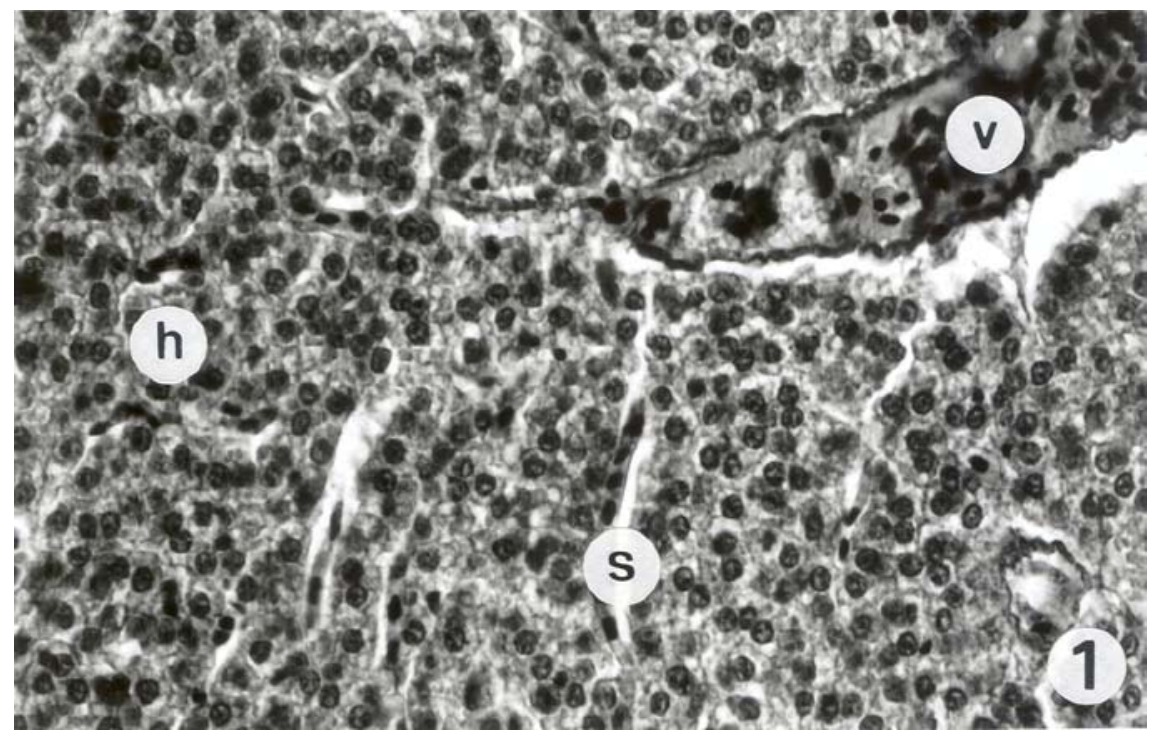

Fig. 1. Section of the liver parenchyma of Oligosarcus jenynsii (h, hepatocytes; s, sinusoid; v, blood vessels). Gomori argentic impregnation. 26x. 


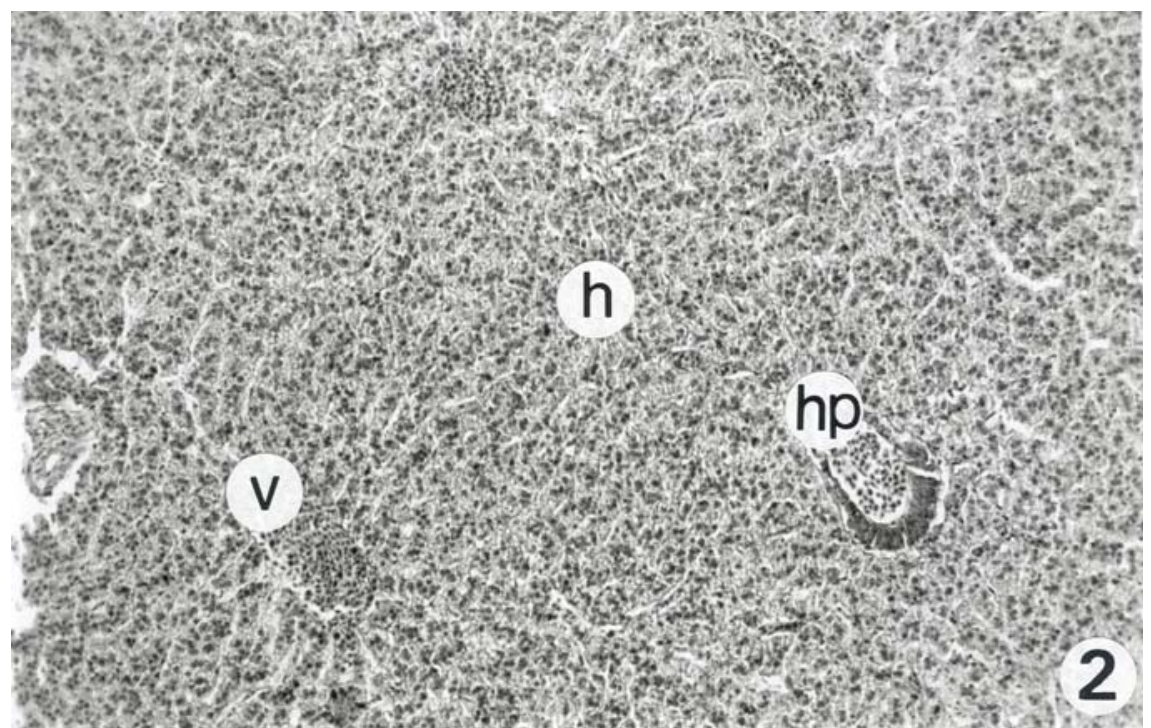

Fig. 2. Section of the liver parenchyma of Oligosarcus jenynsii (h, hepatocytes; hp, hepatopancreas; v, blood vessels). Hematoxylin and Eosin. 2.5x.

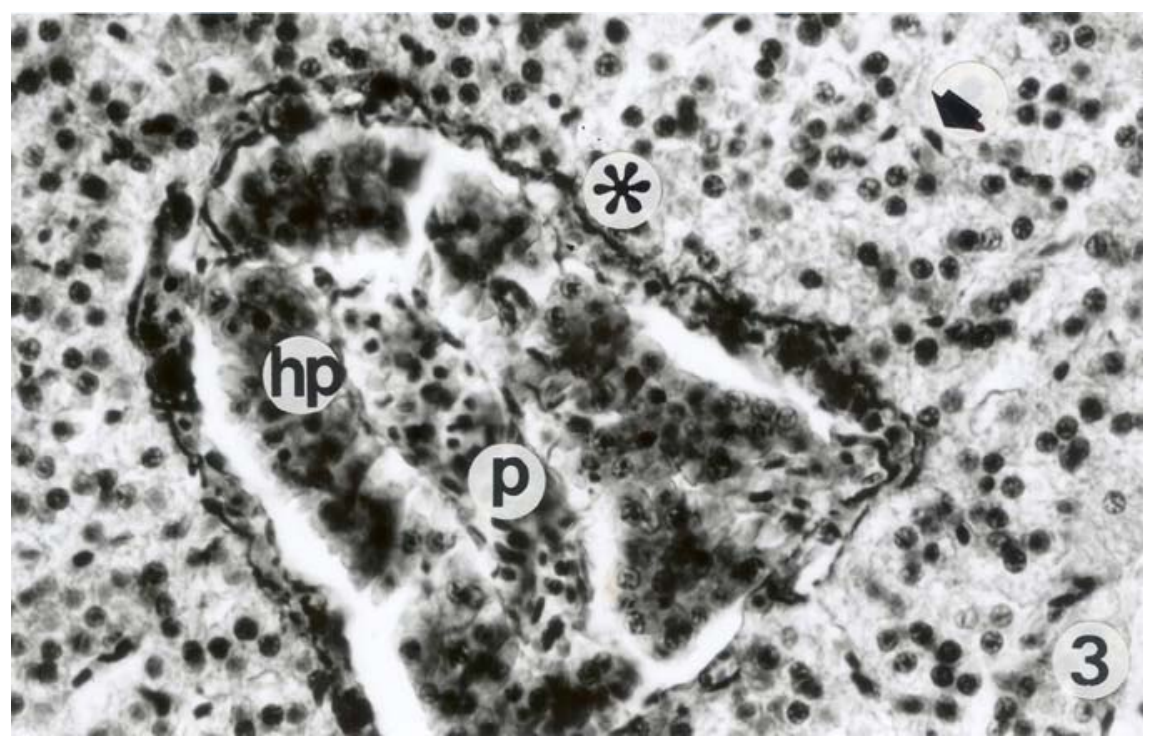

Fig. 3. Hepatopancreas of Oligosarcus jenynsii (hp, hepatopancreas; p, branch of the portal vein; asterisk, reticular fibres; arrow, macrophage). Gomori argentic impregnation. 26x.

as found in higher vertebrates. In $O$. jenynsii, like in many other species including channel catfish Ictalurus punctatus, carp Cyprinus carpio among others, the pancreatic tissue gradually invades the liver along the branches of the portal vein. The combined hepatic and pancreatic tissue are collectively called the hepatopancreas (TAKASHIMA \& HIBIYA, 1995).

The parenchyma is divided by the hepatopancreas into irregular lobules, associated to connective tissue. In these lobules, the hepatocytes are arranged radially around a central sinusoid to form a tubular unit. The histological structure of the liver most closely resembles that described for the Atlantic croaker Micropogon undulatus by EURELL \& HAENSLY (1982), and for the stripped weakfish Cynoscion guatucupa by DíAz et al. (1999).

Hepatocytes of $O$. jenynsii are polyhedral cells. A spherical nucleus was observed centrally or basally in the cell. Fish hepatocytes show not only differences among species, but changes according to age, sex, nutritional state, and spawning season (RocHA et al., 1997).

The hepatocytes of Ictalurus punctatus and Salmo gairdneri usually contain rosette-shaped glycogen, lying close to the sinusoids and bile canaliculi (HINTON \& POOL, 1976). CHAPMAN (1981) and NOPANITAYA et al. (1979) regarded the rosettes containing glycogen as the most prominent property of the hepatocytes of Carassius auratus. Large glycogen deposits were also observed in the liver of the zebrafish, the mosquito fish, and the guppy (WEIss, 1972, 1974). Compared with those of mammals, fish hepatocytes do not metabolize much glycogen (Moon et al., 1985). Some authors described an association among the glycogen and smooth endoplasmic reticulum and occasional lipid droplets in the trout, related to its ability for the synthesis or breakdown of glycogen concordantly to metabolic demand (HINTON \& POOL, 1976). A variation in lipid content has been found, just as of glycogen in $O$. jenynsii hepatocytes, which could be related to the gonadal stage, according to DíAz et al. (1999). 
A typical feature of teleosts is the presence of a diffuse exocrine pancreas, which expands through the mesentery, and forms islets in the connective tissue around some digestive organs, or disseminates within the intraperitoneal adipose tissue (GonZÁLEZ et al., 1993). The localization of the exocrine pancreas in $O$. jenynsii is characteristic of some Actinopterygii, as it is a diffuse organ penetrating the liver to form the hepatopancreas. Shape and arrangement of the acini are similar to the pattern of liver organization of Hydrocynus forskahlii (GEYER et al., 1996), Ictalurus punctatus (HinTon \& Pool, 1976), Micropogon undulatus (EURELl \& HAENSLY, 1982) and Cynoscion guatucupa (DíAZ et al., 1999). The exocrine cells are arranged in acini around small intercellular lumina. In the apical cytoplasm spherical zymogen granules are present, which vary in density (MORRISON, 1987).

In teleosts, the portal veins inside the liver differ from central veins by the presence of pancreatic tissue around the branches of the hepatic portal vein, described by EURELL \& HaEnsly (1982) for the Atlantic croaker Micropogon undulatus. In $O$. jenynsii, the bile ducts and arteries are observed associated to the portal veins and their surrounding pancreatic tissue, whose appearance was not consistent enough to recognize well-defined triads. Similar structures have been described by EURELL \& HAENSLY (1982) for Micropogon undulatus and by DíAz et al. (1999) for Cynoscion guatucupa. However, GonzÁLEZ et al. (1993) established that in Serranus cabrilla triads made up of a ramification of the portal vein, the hepatic artery and the bile duct, are lacking, as observed in most teleosts.

Kupffer cells are involved in the removal and digestion of foreign materials such as bacteria or cancerous and virusinfected cells (Ross et al., 2003).

The results obtained from the present study allow to characterize by light microscopy the normal structure of the liver of $O$. jenynsii.

The liver histomorphology and the organization of exocrine pancreatic tissue in Oligosarcus jenynsii are similar to the acinar morphology from many teleosts, both freshwater and marine species.

\section{REFERENCES}

Campana, M. A.; Panzeri, A. M.; Escalante, A. H.; Moreno, V. J. \& Dulout, F. N. 2001. Micronucleus test in fish from a pampasic pond (Argentina): an estimation of the presence of genotoxic compounds. Journal of Environmental Pathology, Toxicology and Oncology 20(4):325-331.

Chapman, G. B. 1981. Ultrastructure of the liver of the fingerling rainbow trout Salmo gairdneri Richardson. Journal of Fish Biology 18:553-567.

Díaz, A. O.; González Castro, M.; García, A. M.; Devincenti, C. V. \& Goldemberg, A. L. 1999. Morphological and histochemical characterization of liver from stripped weakfish, Cynoscion guatucupa (Cuvier, 1830). Biociencias 7(1):67-78.

Elías, H. \& Bengelsdorf, H. 1952. The structure of the liver of vertebrates. Acta Anatomica 14:297-337.

Escalante, A. H. 1983. Contribución al conocimiento de las relaciones tróficas de peces de agua dulce del Área Platense. II. Otros Tetragonopteridae. Limnobios 2(6):379-402.

Eurell, J. A. \& HaENSLY, W. E. 1982. The histology and ultrastructure of the liver of Atlantic croaker Micropogon undulatus L. Journal of Fish Biology 21:113-125.

Geyer, H. J.; Nel, M. N. \& Swanepoel, J. H. 1996. Histology and ultrastructure of the hepatopancreas of the tigerfish, Hydrocynus forskahlii. Journal of Morphology 227:93-100.

GonzÁlez, G.; CREsPo, S. \& BRUSLE, J. 1993. Histo-cytological study of the liver of the cabrilla sea bass, Serranus cabrilla (Teleostei, Serranidae), an available model for marine fish experimental studies. Journal of Fish Biology 43:363-373.

González Sagrario, M. de los A.; Miglioranza, K. S. B.; Aizpún de Moreno, J. E.; Moreno, V. J. \& Escalante, A. H. 1998. Dynamics of organochlorine compounds in different trophic levels of Los Padres pond in Argentina. I. Pesticides. Environmental Sciences 6:153-169.

. 2002. Dynamics of polychlorinated biphenyls (PCBs) in different trophic levels from a shallow lake in Argentina. Chemosphere 48:1113-1122.

Hinton, D. E. \& Pool, C. H. 1976. Ultrastructure of the liver in channel catfish Ictalurus punctatus (Rafinesque). Journal of Fish Biology 8:209-219.

LANGER, M. 1979. Histologische Untersuchungen an der Teleosteerleber. I. Der Aufbau des Leberparenchyms. Zeitschrift für Mikrosckopisch-Anatomische Forschung 93:829-848.

Magalhães Castro de Tolosa, E.; Junqueira Rodrigues ,C.; Arruda Behmer, O. \& De Freitas Neto, A. G. 2003. Manual de técnicas para histologia normal e patológica. Barueri, Manole. 331p.

Menezes, N. A. 1969. The food of Brycon and three closely related genera of the tribe Acestrorhynchini. Papéis Avulsos de Zoologia 22(20):217-223.

Miglioranza, K. S. B.; Aizpún de Moreno, J. E.; Moreno, V. J.; Osterrieth, M. L. \& Escalante, A. H. 1999. Fate of organochlorine pesticides in soils and terrestrial biota of "Los Padres" pond watershed, Argentina. Environmental Pollution 105:91-99.

Miglioranza, K. S. B.; González Sagrario, M. de los A.; Aizpún de Moreno, J. E.; Moreno, V. J.; Escalante, A. H. \& Osterrieth, M. L. 2002. Agricultural soil as a potential source of input of organochlorine pesticides into a nearby pond. Environmental Science and Pollution Research 9(4):250-256.

Moon, T. W.; Walsh, P. J. \& Mommsen, T. P. 1985. Fish hepatocytes: a model metabolic system. Canadian Journal of Fisheries and Aquatic Sciences 42:1772-1782.

Morrison, C. M. 1987. Histology of the Atlantic cod, Gadus morhua: an atlas. Part One. Digestive tract and associated organs. Canadian Special Publications in Fisheries and Aquatic Sciences 98:1-219.

Mugnaini, E. \& Harboe, S. B. 1967. The liver of Myxine glutinosa: a true tubular gland. Zeitschrift für Zellforschung und Mikroskopische Anatomie 78:341-369.

Nopanitaya, W.; Carson, J. L.; Grisham, J. W. \& Aghajanian, J. G. 1979. New observations on the fine structure of the liver in goldfish (Carassius auratus). Cell Tissue Research 196:249-261.

Petcoff, G. M.; Díaz, A. O.; Escalante, A. H. \& Goldemberg, A. L. 2002. Comparative histology of the kidney of Oligosarcus jenynsi and Rhamdia sapo from Los Padres Lake (Buenos Aires Province, Argentina). Revista Real Academia Galega de Ciencias 21:19-30.

Ringuelet, R. A. 1975. Zoogeografía y ecología de los peces de aguas continentales de la Argentina y consideraciones sobre las áreas ictiológicas de América del Sur. Ecosur 2(3):1-122.

Rocha, E.; Monteiro, R. A. F. \& Pereira, C. A. 1997. Liver of the brown trout, Salmo trutta (Teleostei, Salmonidae): a stereological study at light and electron microscopic levels. The Anatomical Record 247:317-328.

Ross, M.; KaYe, G. \& Pawlina, W. 2003. Histología texto y atlas color con Biología Celular y Molecular. 4 ed. Buenos Aires, Panamericana. $864 \mathrm{p}$.

Takashima, F. \& Hibiya, T. 1995. An atlas of fish histology. Normal and pathological features. 2 ed. Tokyo, Kodansha. $195 \mathrm{p}$.

WEISS, P. 1972. Hepatic ultrastructure in two species of normal, fasted and gravid teleost fishes. The American Journal of Anatomy 133:317-332.

1974. Ultrastructural changes induced by low concentrations of DDT in the livers of the zebrafish and guppy. Chemico Biological Interactions 8:25-30.

Recebido em fevereiro de 2005. Aceito em março de 2006. ISSN 0073-4721

Artigo disponível em: www.scielo.br/isz 